\title{
Effects of Food Deprivation on the Subsequent Growth of the Hatchling Elaphe taeniura friesei in captivity
}

\author{
AKIRA NAKACHI
}

\begin{abstract}
Two groups of hatchling Elaphe taeniura friesei were reared under different feeding schedules for one year. One group (group $A ; N=15$ ) was offered food from the completion of their first shedding, whereas the other (group $B ; N=14$ ) was first fed after food deprivation for two months. The mean body weight (BW) loss in group $B$ during the food deprivation period was $2.99 \%$ / week. During this period, snakes of group $A$ grew in snout-vent length (SVL) 1.5 times and in body weight (BW) 5.9 times larger than the snakes of group B. Significant differences were recognized in both parameters between the two groups. During the first year, both groups consumed about an equal amount of food, but the SVL of group A became significantly greater than that of group B. There were, however, no significant differences in BW between groups $A$ and $B$. Group B exhibited a significantly higher monthly feeding rate and monthly conversion efficiency than group $A$. These results suggest that the food deprivation period affected subsequent feeding rates and growth rates of the hatchling snakes.
\end{abstract}

Key words: Serpentes; Elaphe taeniura friesei; Growth; Food deprivation; Captivity

Several researchers have stated that growth of captive snakes is directly related to the amount of food consumed (Barnard et al., 1979; Ford, 1974; Kamura and Shimamura, 1980; Moriya and Higashizono, 1986, 1991; Smith, 1976). Some studies have further attempted to analyze the relationship between feeding schedule and growth of captive snakes. Myer and Kowell (1971, 1973), for example, conducted experiments by depriving captive snakes of food for certain periods. Weight losses in adult Lampropeltis getulus floridana and hatchling Thamnophis sirtalis were small even during the food deprivation period, and the lost weight of the latter rapidly recovered during the subsequent feeding period. Mori (1987) compared growth among three groups of juvenile Rhabdophis tigrinus tigrinus fed at different intervals, and found that the growth of the juveniles was affected by the feeding schedule. On the other hand, Charland and Gregory (1989) stated that in two groups of adult female Crotalus viridis subjected to different feeding schedules in captivity, no correlation was recognized between weight gain and the amount of food intake.

However, there is little information on the relationship of growth of snakes with feeding schedule and amount of food consumption. This study was conducted to clarify the effects of prolonged food deprivation on the body weight,

Accepted 15 May 1992 as well as on the subsequent food intake and growth in snakes.

\section{Materials ANd Methods}

Twenty-nine hatchlings of the Taiwanese rat snake, Elaphe taeniura friesei, from two clutches, hatched in the laboratory, were used. The mother snakes were brought from Taiwan by a commercial dealer. They laid eggs on 16 and 24 May 1988, which hatched from 23 to 27 and 15 to 19 August 1988, respectively. Hatchlings were housed individually in cages $37 \times 34 \times 18 \mathrm{~cm}$ in size from the day of hatching. They were divided randomly into two groups-group A (seven males and eight females) and group B (nine males and five females).

A small container filled with water was kept in each cage at all times. Temperature of the experimental room was maintained at 22.5-26.0 C during the experimental period. Photoperiod of the room was not regulated, and the sunlight entering through the windows was the only light source for the room.

I started the feeding of group A from 10 September 1988 (21 days after hatching) when they completed their first shedding. I deprived group B of food for two months after their hatching, and offered food from 11 November 1988. I offered laboratory mice (both live and dead) to the snakes, once or twice a week. First a single mouse was offered to each snake, and additional mice were offered if the first mouse was 
TABLE 1. Measurements of snout-vent length (SVL, cm), body weight $(\mathrm{BW}, \mathrm{g})$ and cumulative food consumption (CFC, g) (mean $\pm \mathrm{SD}$, range in parentheses) in Elaphe taeniura friesei, and results of their statistical comparison between groups A and B by Mann-Whitney's U-test.

\begin{tabular}{|c|c|c|c|c|c|c|c|c|c|}
\hline \multirow{2}{*}{\multicolumn{2}{|c|}{$\mathrm{N}$}} & \multicolumn{2}{|c|}{$\begin{array}{l}\text { At the beginning } \\
\text { of study } \\
10 \text { SEP } 1988\end{array}$} & \multicolumn{3}{|c|}{$\begin{array}{l}\text { At the end of food } \\
\text { deprivation of group B } \\
\text { 10 NOV } 1988\end{array}$} & \multicolumn{3}{|c|}{$\begin{array}{l}\text { At the end of study } \\
11 \text { AUG } 1989\end{array}$} \\
\hline & & SVL & BW & SVL & BW & CFC & SVL & BW & CFC \\
\hline \multicolumn{10}{|l|}{ Group A } \\
\hline Male & 7 & $39.3 \pm 2.0$ & $14.6 \pm 2.2$ & $57.0 \pm 5.1$ & $63.2 \pm 18.1$ & $118.0 \pm 37.1$ & $111.6 \pm 8.5$ & $380.3 \pm 77.5$ & $916.6 \pm 160.4$ \\
\hline Female & 8 & $40.2 \pm 2.0$ & $16.5 \pm 0.9$ & $61.0 \pm 2.3$ & $74.1 \pm 6.5$ & $142.1 \pm 9.1$ & $113.8 \pm 6.1$ & $400.4 \pm 55.1$ & $995.6 \pm 123.8$ \\
\hline Total & 15 & $\begin{array}{c}39.8 \pm 2.1 \\
(35.7-42.6)\end{array}$ & $\begin{array}{c}15.6 \pm 1.9 \\
(9.9-17.5)\end{array}$ & $\begin{array}{c}59.2 \pm 4.4 \\
(47.6-63.2)\end{array}$ & $\begin{array}{l}69.0 \pm 14.3 \\
(31.9-83.8)\end{array}$ & $\begin{array}{c}130.9 \pm 28.8 \\
(47-157)\end{array}$ & $\begin{array}{c}112.8 \pm 7.4 \\
(96.2-124.2)\end{array}$ & $\begin{array}{c}391.0 \pm 67.3 \\
(257-511)\end{array}$ & $\begin{array}{c}958.7 \pm 147.5 \\
(656-1150)\end{array}$ \\
\hline \multicolumn{10}{|l|}{ Group B } \\
\hline Male & 9 & $39.1 \pm 1.6$ & $16.3 \pm 0.9$ & $39.2 \pm 1.2$ & $11.9 \pm 0.9$ & - & $106.4 \pm 3.9$ & $379.2 \pm 47.6$ & $848.1 \pm 84.4$ \\
\hline Female & 5 & $38.7 \pm 1.6$ & $15.0 \pm 2.2$ & $39.2 \pm 2.1$ & $11.3 \pm 1.3$ & - & $111.5 \pm 3.8$ & $409.4 \pm 34.3$ & $900.8 \pm 102.1$ \\
\hline Total & 14 & $\begin{array}{c}39.0 \pm 1.6 \\
(36.1-41.6)\end{array}$ & $\begin{array}{c}15.8 \pm 1.6 \\
(11.1-18.0)\end{array}$ & $\begin{array}{c}39.2 \pm 1.6 \\
(36.2-42.2)\end{array}$ & $\begin{array}{c}11.7 \pm 1.1 \\
(9.2-13.2)\end{array}$ & - & $\begin{array}{c}108.3 \pm 4.6 \\
(100.8-118.3)\end{array}$ & $\begin{array}{c}390.0 \pm 45.7 \\
(293-451)\end{array}$ & $\begin{array}{c}866.9 \pm 94.5 \\
(684-1004)\end{array}$ \\
\hline \multicolumn{10}{|c|}{ Comparison between groups A and B } \\
\hline & & $\mathrm{p}>0.05$ & $\mathrm{p}>0.05$ & $\mathrm{p}<0.01$ & $\mathrm{p}<0.01$ & - & $\mathrm{p}<0.05$ & $\mathrm{p}>0.05$ & $\mathrm{p}>0.05$ \\
\hline
\end{tabular}

eaten within six hours. If the snake did not eat the first mouse within six hours, additional mice were not provided. Even in that case, however, the first mouse was left in the cage for 18 hours. I then checked each cage to see if the mouse had been eaten (accepted) or not, and removed the mouse if it still remained. After starting the feeding for group B, I reduced the amount of food offered to group $A$ at each feeding so as to make snakes of both groups consume an equal amount of food during the first year after hatching.

I recorded the amount of food consumed by each snake at each feeding (FC: weight of mouse, in $\mathrm{g}$ ), and measured snout-vent length (SVL, in $\mathrm{cm}$ ) and body weight (BW, in $\mathrm{g}$ ) of each snake monthly. These observations were continued to 11 August 1989, approximately one year after the hatching. Feeding rates (FR) were calculated as:

$$
\frac{\begin{array}{c}
\text { number of feeding trials in which } \\
\text { the prey was accepted } \times 100
\end{array}}{\text { total number of feeding trials }}
$$

Taking Sheldon's (1983) arguments on conversion efficiency (CE) into consideration, monthly conversion efficiency (MCE) was calculated as:

$$
\frac{\text { monthly increment of BW } \times 100}{\text { monthly FC }}
$$

for the analysis of CE. Differences among means were tested for statistical significance by Mann-Whitney's U-test, and correlations among growth parameters were tested by examining Ken- dall's rank correlation coefficient.

\section{Results}

SVL, BW, and cumulative amount of food consumed (CFC) at the beginning of the study, at the end of food deprivation period of group $B$, and at the end of the study are listed in Table 1 for each group and sex. During the two months of food deprivation, group B exhibited a slight increment of mean SVL $(0.4 \%)$ and a distinct decrement of mean BW (26.0\%): mean BW loss of group B was $7.3 \%$ during the first month of the food deprivation period, and $20.2 \%$ during the second. All individuals of group B survived the food deprivation period, and they constantly accepted food provided thereafter. During the food deprivation period

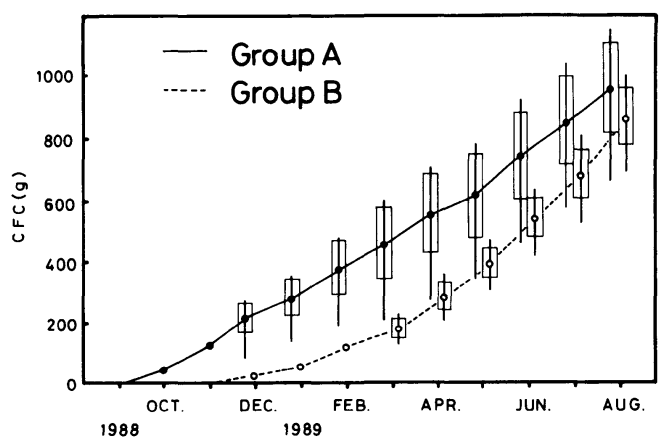

FIG. 1. Cumulative food consumption (CFC) in groups A and B of Elaphe taeniura friesei. Circles, rectangles, and vertical lines represent mean values, ranges of standard deviation from means, and ranges of raw values, respectively. 


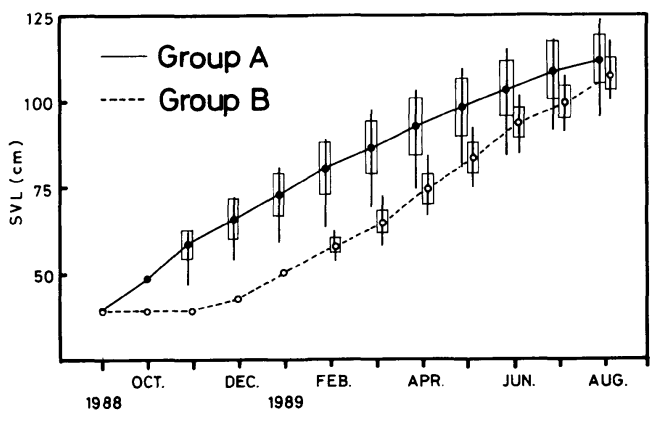

FIG. 2. Growth in SVL of Elaphe taeniura friesei. Notations as in Fig. 1.

of group B, snakes of group A fed and grew in SVL 1.5 times and in BW 5.9 times larger than those of group B (Figs. 2 and 3). In both of these parameters, the differences were statistically significant $(p<0.01)$.

Mean CFC at the end of the observation period was slightly larger in group A, but no statistical difference was recognizable from that in group B ( $>0.05)$; the two groups consumed approximately an equal amount of food during one year from hatching (Fig. 1). There were no significant differences between mean SVLs of the two groups at the beginning of the study $(p>0.05)$. But SVL of group A $(\bar{x}=112.8 \mathrm{~cm})$ had grown significantly greater than that of group B $(\bar{x}=108.3)$ at the end of the study ( $<<0.05$; Fig. 2). No significant differences, on the other hand, were recognized in BW between the two groups at either the beginning or the end of the study ( $p>0.05$; Fig. 3). Females were slightly greater in CFC, SVL, and BW than males within each group at the end of the study, but there were no significant sexual differences in these parameters within each group $(p>0.05)$.

During the feeding period, both monthly feeding rate (MFR) and MCE exhibited different

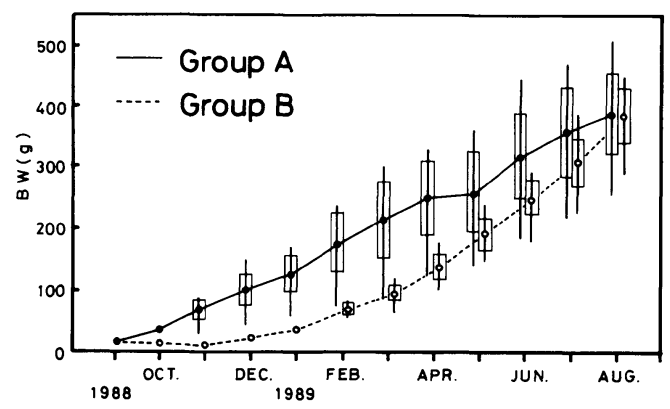

FIG. 3. Growth in BW of Elaphe taeniura friesei. Notations as in Fig. 1.

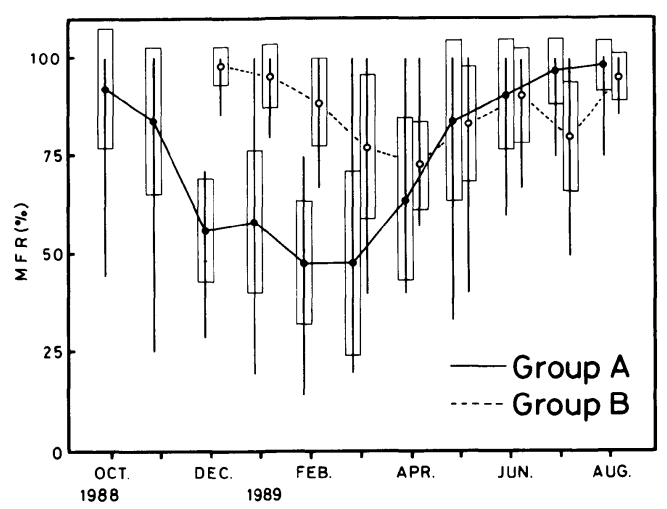

FIG. 4. Changes in monthly feeding rates (MFR) in groups $\mathrm{A}$ and $\mathrm{B}$ of hatchling Elaphe taeniura friesei. Notations as in Fig. 1.

patterns of change between groups $\mathrm{A}$ and $\mathrm{B}$. The MFR (\%) of group A fell to the lowest point in February $(\bar{x}=47.62, S D=15.69)$, and that of group B did so in April $(\bar{x}=72.45, S D=11.41$; Fig. 4). The MCE of group A exhibited fluctuation and some individuals exhibited very low values, whereas that of group B remained relatively steady and was higher than that of group A during most of the feeding period (Fig. 5). There was no correlation between MFR and MCE, and monthly FC/BW (p>0.05). The mean MFR in group A was $74.62 \pm 25.35 \%$ $(\bar{x} \pm S D)$ and that in group $B$ was $86.80 \pm$ $14.78 \%$, and the mean MCE in group $A$ was $37.88 \pm 18.78 \%$, and that in group B was $45.55 \pm$ $9.04 \%$. Both rates were significantly higher in group B than in group A $(p<0.01)$. There were no significant sexual differences in MFR or MCE within each group ( $p>0.05)$.

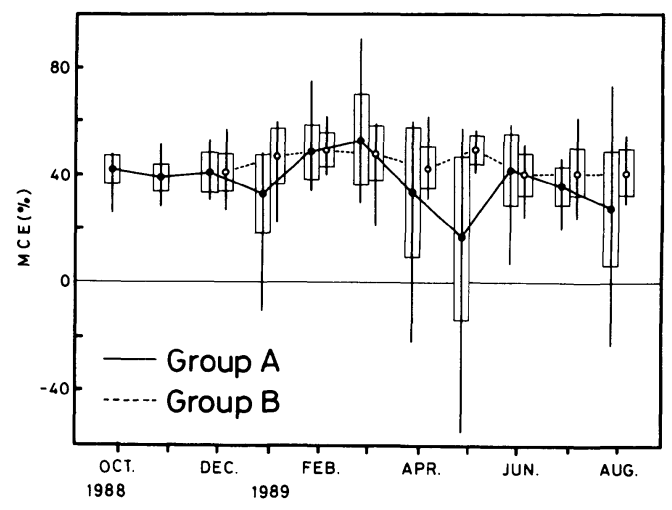

Fig. 5. Changes in monthly conversion efficiency (MCE) in groups A and B of hatchling Elaphe taeniura friesei. Notations as in Fig. 1. 


\section{Discussion}

Myer and Kowell $(1971,1973)$ reported that weight losses of adult Lampropeltis getulus floridana and hatchling Thamnophis sirtalis during food deprivation periods were $6.3 \% / 6$ weeks $(1.05 \% /$ week) and 6.72 to $7.50 \% / 2$ weeks $(3.36$ to $3.75 \% /$ week), respectively. Weight loss of hatchling $E$. $t$. friesei observed in the present study was $26.0 \% / 8.7$ weeks $(2.99 \% /$ week) during the food deprivation period. This value is similar to that in hatchling $T$. sirtalis and higher than that in adult L. g. floridana. This seems to have resulted from the higher metabolic rates in juvenile snakes than in adults. Snakes generally utilize the remnant of embryonic yolk as an energy source during the first few weeks after hatching (Andrews, 1982). In this experiment, food deprivation was begun soon after hatching. Therefore, it could be predicted that group B would exhibit a slight increment in SVL during that period, and that the rate of $\mathrm{BW}$ loss for the first month would be lower than for the second month. Accordingly, the actual starvation period of group $B$ seems to have been shorter than the actual food deprivation period.

In the present experiment, the two groups which consumed a nearly equal amount of food through different feeding schedules attained similar growth in BW. This result supports the idea that the growth of snakes greatly depends upon the food intake (Barnard et al., 1979; Ford, 1974; Kamura and Shimamura, 1980; Smith, 1976). However, the two groups did not attain similar growth in SVL; group B was smaller than group A. These results support the idea that the amount of food consumption is more related to growth in BW rather than body length of snakes (Kamura, 1975; Mori, 1987; Moriya and Higashizono, 1986, 1991).

Kamura (1975) observed that one juvenile Trimeresurus flavoviridis which had shown lower growth rates in SVL and BW than others by refusing food during the first year attained a size equal to that of the others at the third year by subsequent spontaneous feeding. In captive juvenile Rhabdophis t. tigrinus (Mori, 1987) and captive juvenile Agkistrodon blomhoffi brevicaudus (Moriya and Higashizono, 1991), it was observed that increment of body length was preceded by increment of BW. There is, therefore, a possibility that difference of SVL between groups $\mathrm{A}$ and $\mathrm{B}$ would disappear if prolonged observations were made. These results suggest that duration of starvation did not deprive the snakes of potential growing ability, and dur- ing subsequent feeding periods, snakes can almost annul the difference of growth in SVL and BW caused by the preceding treatment.

In the present study, a simple correlation was suggested between the amount of food consumed and growth of snakes. Even so, however, the process of growth showed different patterns in groups A and B. Differences were recognized in MFR and MCE between the two groups, and there was no correlation among MFR, MCE, and monthly FC/BW. Thus, changes in these parameters may be due to internal causes in the snakes, and it is probable that differences in both parameters between the two groups arose from the different feeding schedules.

Hatchling $E$. $t$. friesei subjected to a starvation period had a higher mean MFR than hatchlings fed from the beginning. Myer and Kowell (1973) reported that a group of hatchling $T$. sirtalis, offered food at long intervals in captivity, tended to take a larger amount of food voluntarily at each feeding than those fed more frequently. Mori (1987) reported that captive juvenile $R$. $t$. tigrinus subjected to lower food availability, continued to eat later in winter. The higher mean MFR of group B might be indicative of adaptation to a variable feeding schedule in nature.

Group B also had a higher mean MCE than group A. This might have resulted from adaptation to a shortage of food resources. Charland and Gregory (1989) reported that the mean BWs of two groups of adult female Crotalus viridis, kept under different feeding conditions, remained virtually identical during the four-month study period, and stated that no correlation were recognized between weight gain and amount of food intake. This seems to imply that snakes could adjust some growth parameters against changes in feeding schedules.

Relationships between feeding conditions and growth parameters in ectothermal vertebrates have been discussed by many authors (Charland and Gregory, 1989; Pough, 1980; Smith, 1976; Stevenson et al., 1985). In snakes, Stevenson et al. (1985) observed relationships among body temperature, oxygen consumption, and digestion speed of captive Thamnophis elegans, and suggested that snakes may conserve energy resources by minimizing body temperature and metabolic rate when food is unavailable. Thus, it is probable that, in the present study, difference of MCE in the two groups might have resulted from difference in body temperature and metabolic rate caused by the different feeding schedules. 
ACKNowledgments. - I wish to thank H. Ota, A. Mori and M. Toriba for literature, and H. Ota for carefully reading an early draft of this paper. This research was conducted in the facility of the Japan Snake Institute Okinawa Branch.

\section{Literature Cited}

Andrews, R. M. 1982. Patterns of growth in reptiles. In: Gans, C. and F. H. Pough (eds.), Biology of Reptilia, Vol. 13. p.273-320. Academic press, New York.

Barnard, S. M., T.G. Hollinger AND T. A. RoMAINE. 1979. Growth and food consumption in the corn snake, Elaphe guttata guttata (Serpentes: Colubridae). Copeia 1979(4) : 739-741.

Charland, M. B. AND P. T. Gregory. 1989. Feeding rate and weight gain in postpartum rattlesnakes: Do animals that eat more always grow more? Copeia 1989(1) : 211-214.

FORD, N. B. 1974. Growth and food consumption in the yellow rat snake, Elaphe obsoleta quadrivittata. Herpetologica 30(1) : 102-104.

KAMURA, T. 1975. Rearing of young habu (Trimeresurus flavoviridis) in laboratory. I. Observations for three years. Rep. Okinawa Pref. Inst. Publ. Health (9) : 127-138. (in Japanese)

KAmURA, T. AND K. Shimamura. 1980. Rearing of habu (Trimeresurus flavoviridis) in laboratory. II. Observations for seven years. Rep. Okinawa Pref. Inst. Publ. Health (14) : 59-73. (in Japanese)

Mori, A. 1987. Growth pattern in the juvenile Japanese grass snake, Rhabdophis tigrinus tigrinus, in captivity. Jpn. J. Herpetol. 12(1) : 1-9.

\section{要旨 タイワンスジオの概化幼蛇における飼育 下での絶食がその後の成長に与える影響}

仲地 明

2 群のタイワンスジオの餒化幼蛇を異なった 餌条件下で 1 年間飼育した。A 群（15個体） には初回の脱皮終了後より給餌し, B 群（14個 体）は餒化から 2 力月間飢餓状態に打いた後に 給慨を開始した. 絶食期における B 群の体重 の減少は $2.99 \% /$ 週であった。 B 群の絶食期間 中に A 群は捕食・成長し頭胴長および体重で それぞれ B 群の 1.5 倍および 5.9 倍となり, 両 群間に有意な成長差を確認した。しかし粰化よ
Moriya, A. AND S. Higashizono. 1986. Growth and food consumption in the mamushi, Agkistrodon blomhoffii blomhoffii, (Boie), in captivity. Jpn. J. Herpetol. 11(3) : 110-123.

Moriya, A. AND S. Higashizono. 1991. Growth and food consumption in short-tailed mamushi, Agkistrodon blomhoffii brevicaudus, in captivity. Jpn. J. Herpetol. 14(1) : 15-20. (in Japanese, with English abstract)

MYER, J. S. AND A. P. Kowell. 1971. Eating pattern and body weight change of snakes when eating and when food deprived. Physiol. Behav. 6 : 71-74.

MYeR, J. S. AND A. P. Kowell. 1973. Effects of feeding schedule and food deprivation on the growth of neonatal garter snakes (Thamnophis sirtalis). J. Herpetol. 7(3) : 225-229.

Pough, F. H. 1980. The advantages of ectothermy for tetrapods. Am. Nat. 115:92-112.

Sheldon, A. L. 1983. Food and growth relationships: A comment on statistical analysis. Copeia 1983(4) : 1090-1092.

Smith, G. C. 1976. Ecological energetics of three species of ectothermic vertebrates. Ecology 57(2) : 252-264.

Stevenson, R. D., C. R. Peterson and J. S. Tsuji. 1985. The thermal dependence of locomotion, tongue flicking, digestion, and oxygen consumption in the wandering garter snake. Physiol. Zool. 58(1) : 46-57.

Yonabaru 11-1, Yonabaru, Shimajiri-gun, Okinawa, 901-13 JAPAN

り 1 年後に両群は等しい累積量の餌を摂取し, 頭胴長では A 群が大きかったが，体重に成長 差は認められなかった. 両群の給慨期間中の月 間捕食率および月間転換率はB 群で有意に高 い值が観察された。この結果は, 飢餓期の存在 がその後の捕食率および成長率に影響を与える ことを示唆している.

（901-13 沖縄県島尻郡与那原町字与那原11-1） 